IRSH 54 (2009), Supplement, pp. 9I-I I 4 doi:I0.I0I 7/So020859009990253

(C) 2009 Internationaal Instituut voor Sociale Geschiedenis

\title{
Vertical Bazaars of Modernity: Western Department Stores and Their Staff in Istanbul (I889-I92 I)*
}

\author{
YAVUZ K ÖSE \\ Institute of Near and Middle Eastern Studies, \\ Ludwig Maximilian University
}

E-mail: y.k@lmu.de

Summary: This article examines Western department stores active in Istanbul between I 889 and I92I. It explores two aspects crucial for the department stores' retail system: location and personnel. It goes on to demonstrate that Western department stores were situated not only in the Western districts of the city but also in traditional areas, such as the bazaar district. Rather than being exclusive they appear to have been closely connected with local business and aimed to appeal to the ethnically highly mixed customer pool. Equally, the workforce was heterogeneous, with the majority of local employees having diverse ethnic backgrounds, including Greek, Jewish, and Armenian, though rarely Muslim. Based on a largescale sample drawn from the address registers of the Annuaire Oriental yearbook, the analysis of personal letters, and on Ottoman daily newspaper and journals, this study sheds light on the individuals who worked at a number of department stores, their ethnic composition, sex ratio, duration of employment, the job types they carried out, as well as their income situation, career paths, and domiciles. It hopes to contribute to the labour history of the late Ottoman Empire by exploring, for the first time, the employees of Western department stores, workers who have rarely attracted the attention of scholars so far.

Istanbul today offers very different shopping experiences, ranging from the Grand Bazaar founded in the fifteenth century - one of the largest covered markets in the world - to the Cevahir shopping mall, the second largest in Europe. The Grand Bazaar offers the consumer more than 3,000 shops, distributed according to product categories along 64 streets, with a total gross area of around 300,000 square metres. In contrast, the Cevahir mall, which opened in Şişli at the end of 2005 , has a total gross area of

\footnotetext{
* This study is based on "Basare der Moderne von Pera bis Stamboul und ihre Angestellten", in Yavuz Köse (ed.), Istanbul: vom imperialen Herrschersitz zur Megapolis. Historiographische Betrachtungen zu Gesellschaft, Institutionen und Räumen (Munich, 2006), pp. 314-35 I.
} 
around 420,000 square metres, hosting more than 340 shops on 10 floors, as well as providing parking for 2,500 cars.

Contemporary Istanbul has more mega malls than any other European city, and these modern malls have much in common with the Grand Bazaar, similarly offering a wide range of goods in separate shops organized along "streets". The most obvious difference is that whereas the Grand Bazaar is planned horizontally, the modern malls are multi-storeyed; they might therefore be characterized as vertical bazaars. ${ }^{2}$

Almost a century ago, in I9I2, Alfred Wiener compared bazaars with Western department stores, which first began to appear in the I860s and I870s, first in European and then in American cities. ${ }^{3}$ They too offered a varied assortment of goods under the same roof; like contemporary malls, they did this on multiple floors. But, as Wiener stressed, the most fundamental difference between bazaars (we should add malls) and department stores is to be found in the way both were managed. Each store in the Grand Bazaar has its own proprietor, whereas the department store is owned by one person or a group of persons. The Grand Bazaar, and malls such as Cevahir, employ several thousand workers; yet they do not form a united workforce under a single management. Whether 50 or 5,000 employees work in a department store, they all report to one management. ${ }^{4}$

Another characteristic that distinguishes bazaars from Western department stores is that some of the latter operate branches nationally and internationally. Since the last quarter of the nineteenth century, some Western department stores had run a dense network of branches covering many important Ottoman cities, including Beirut, Cairo, Istanbul, Izmir, and Thessalonica. Their cosmopolitan populations, comprising Europeans, Levantines, Armenians, Greeks, Jews, and an ever-growing number of Muslim "bourgeoisie" with an inclination to Western-style consumer behaviour, were the target of those enterprises. Although none of those enterprises is active today, some survived until the I950s, and we can still find contemporary witnesses who remember them.' In cities such as

I. Tuna Taşan-Kok, “Turkish Shopping Center Development Goes International Balancing the Risks and Opportunities of Investing in a Hot Market", Research Review, I 5:2 (2008), pp. 39-44; Feyzan Erkip, "The Rise of the Shopping Mall in Turkey: The Use and Appeal of a Mall in Ankara”, Cities, 22:2 (2005), pp. 89-108.

2. For an illustrative overview of the evolution of Western shopping buildings, see Chuihua Judy Chung et al. (eds), The Harvard Design School Guide to Shopping (Cologne, 200I).

3. Alfred Wiener (ed.), Das Warenhaus. Kauf-, Geschäfts-, Büro-Haus (Berlin, I9I2). See also Karl Zaar and August Leo Zaar, "Geschäfts- und Kaufhäuser, Warenhäuser und Messpläste, Passagen oder Galerien”, Handbuch der Architektur, 4, Halbband 2, Heft 2 (Stuttgart, I902). 4. Heinz-Gerhard Haupt, Konsum und Handel. Europa im 19. und 20. Jabrbundert (Göttingen, 2003), p. 73 .

5. Rifat N. Bali, "Mayer Mağazası ve Georg Mayer”, in Georg Mayer, Türk Çarşısı. Şark'ta Ticaretin Püf Noktalar, trans. Yusuf Öztel, annot. Rifat Bali (Istanbul, 2008), pp. viii-xxxix. 
Cairo, Thessalonica, and Istanbul, a few of their buildings still exist, testifying to their former greatness. ${ }^{6}$

This study focuses on two aspects: the employees and the spatial distribution of Western department stores in Istanbul. The location, along with the personnel, was an important pillar of the department store's innovative retail system. This becomes clear if we consider its most important business features. ${ }^{7}$ Those were: a central location within urban areas; low rent (multi-storey premises); low product prices (low calculated prices for high-quality goods); low increases in prices; high sales, high stock turnover; large variety of goods, categorized and arranged openly in various departments (no obligation to buy); different sales floors and checkouts; and a high number of sales personnel and staff.

One of the main aims of department stores was to attract as many customers as possible and to offer them cheap goods in a highly appealing manner. The low prices were possible owing to high stock turnover. ${ }^{8}$ This strategy has had a deep influence on the "traditional" retail store. With their abundance and variety of goods, department stores squeezed many retail traders out of the market. ${ }^{9}$ Further, they aroused dissent among Western and Ottoman society alike; department stores were not only innovative in their marketing, they became public places where men and women could stroll through the world of goods and consumption. One might even argue that, with them, the clear distinction between private and public began to disintegrate. ${ }^{10}$

The situation that prevailed when Western department stores entered the Ottoman urban market was replete with challenges. To approach the ethnically, culturally, and linguistically mixed customer pool, department

6. Yavuz Köse, Westliche Konsumgüterunternehmen am Bosporus. Markt, Marketing und gesellschaftliche Reaktionen im späten Osmanischen Reich (1855-1923) (forthcoming); and Rudolf Agstner, "Dream and Reality: Austrian Architects in Egypt, I869-1914", in Mercedes Volait (ed.), Le Caire-Alexandrie. Architectures européennes, 1850-1950 (Cairo, 200I), pp. I 49-155.

7. Hrant Pasdermadjian, The Department Store: Its Origins, Evolution and Economics (London, 1954), pp. 9-10; Tim Coles, "Department Stores as Innovations in Retail Marketing: Some Observations on Marketing Practice and Perception in Wilhelmine Germany", Journal of Macromarketing, I9 (1999), pp. 37-47; and Heidrun Homburg, "Warenhausunternehmen und ihre Gründer in Frankreich und Deutschland: eine diskrete Elite und mancherlei Mythen", Jabrbuch für Wirtschaftsgeschichte, (1992), pp. 183-219, 185-186.

8. Homburg, "Warenhausunternehmen und ihre Gründer", pp. 185-186.

9. Geoffrey Crossick and Heinz-Gerhard Haupt (eds), Shopkeepers and Master Artisans in Nineteenth-Century Europe (London [etc.], 1984); Uwe Spiekermann, Basis der Konsumgesellschaft. Entstebung und Entwicklung des modernen Kleinhandels in Deutschland I850-19I4 (Munich, I999).

Io. Haupt, Konsum und Handel, pp. 65-90; Erica Carter, "Frauen und die Öffentlichkeit des Konsums", in Heinz-Gerhard Haupt and Claudius Torp (eds), Die Konsumgesellschaft in Deutschland I890-1990. Ein Handbuch (Frankfurt am Main, 2009), pp. I54-I7I. 
stores had to widen their marketing by using all the available media that those different groups used. Likewise, the question of location was crucial since, for example, Muslim female customers would not easily visit branches located in Western districts. To attract them, stores had to be located in easily accessible areas; also, special rooms and personnel had to be provided. ${ }^{\text {II }}$ Western department stores were reconciled to such factors for their businesses in Istanbul. Whereas the choice of location clearly shows that they established themselves equally in Western and "Muslim" districts alike, the situation was somewhat different in terms of personnel.

This study seeks to present some basic data on the workforce of Western department stores active in Istanbul between the years I 889 and I92I. Those stores have not, it would seem, attracted much interest among scholars, which is surprising if we consider that department stores active in the Ottoman Empire might have had several hundred employees. ${ }^{\text {I2 }}$ Who were those employees, working on "the frontline of consumption" as Bill Lancaster put it? ${ }^{13}$ It is not easy to find out, since we lack the first-hand sources and business archives which would otherwise have allowed us to gain some insight into the day-to-day business, the staff, and organizational structure. One is obliged therefore to consider a wide range of sources which, although "secondary", nonetheless help us to understand the economic, social, and cultural importance of those businesses. One of the most interesting sources on employees is the socalled Annuaire Oriental yearbook (hereafter $A O) .{ }^{14}$ Since we lack rosters for department stores active in Istanbul, the $A O$ helps us to analyse - if only partly - employees over a period of around thirty years. Moreover, the listings allow us to differentiate between the sex, job type, length of employment, and even the domicile of the employees. ${ }^{15}$ With additional sources such as personal letters and the contemporary Ottoman press, we are able partly to compare the income of those employees within the

I I. See Hanımlara Mabsus Gazete, 26 Kanun-i evvel I3 I 2 [7 January]/ı897, p. 4.

I2. Among the few authors who have studied department stores and addressed the issue of employees are Rudolf Agstner, "Das Wiener Kaufhausimperium 'S. Stein' im Osmanischen Reich", Wiener Geschichtsblätter, 59 (2004), pp. I30-I40; Nancy Young Reynolds, "Commodity Communities: Interweavings of Market Cultures, Consumption Practices, and Social Power in Egypt, I907-196I" (unpublished Ph.D. dissertation, Stanford University, 2003); Uri Kupferschmidt, European Department Stores and the Middle Eastern Consumers: The OrosdiBack Saga (Istanbul, 2007); idem, "Who Needed Department Stores in Egypt? From OrosdiBack to Omar Effendi”, Middle Eastern Studies, 43 (2007), pp. 175-192; Yavuz Köse, “'Maintenant, le plus beau, c'est la grève des EOB': Ein Französischer Warenhausangestellter im Osmanischen Reich oder wie ein Streik funktioniert”, Archivum Ottomanicum, 24 (2007), pp. 103-145, and idem, "Basare der Moderne".

I3. Bill Lancaster, The Department Store: A Social History (London [etc.], 1995).

I4. Turgut Kut, "Indicateur Ottoman: Şark Ticaret Yıllıkları", Simurg. Kitap Kokusu, I (1999), pp. I 86-199.

I 5. Köse, "Basare der Moderne". 
broader context of European department stores and the urban Ottoman workforce. To analyse spatial distribution, besides the $A O$ advertisements in the multilingual local press were highly informative.

\section{CHOICE OF LOCATION: BETWEEN THE GRAND RUE DE PERA AND THE GRAND BAZAAR}

Despite what many Western observers claimed, the $A O$ and the advertisements in the Ottoman press clearly show that department stores were located not only in the Western districts of the capital. ${ }^{16} \mathrm{It}$ is true that, from the second half of the nineteenth century, Galata/Pera became an important shopping centre and the famous Grand Rue de Pera (today's Istiklal Caddesi) and its side streets had the highest density of Western stores. ${ }^{17}$ But the old city (Stamboul) too was a prominent location for such enterprises and their branches. There was often assumed to be a clear-cut separation between the modern districts of the city, where an "accurate business system" was to be found, and the old city, with its Great Bazaar, which was described as "cramped quarters of native merchants". ${ }^{18}$

For Henry Otis Dwight, for instance, crossing the Galata Bridge must have meant leaving modernity and entering backwardness. Yet, Western department stores did not follow such simplified categories in their choice of location. When looked at in terms of business, it was profitable to apply a successful concept (high turnover - low prices) in various areas. The close location to the Bazaar not only provided easy access to retailers and traders; the stream of pedestrians must also have been an incentive. Furthermore, the close proximity to the port (Eminönü-Karaköy) provided another benefit in terms of logistics and distribution. Finally, in Stamboul, besides the Grand Bazaar and Western department stores we also find Muslim department stores with "orientalized" facades adorning their multi-storey premises and

16. For Galata and Pera see Edhem Eldem, "Ottoman Galata and Pera Between Myth and Reality", in Ulrike Tischler (ed.), From "mileu de mémoire" to "lieu de mémoire". The Cultural Memory of Istanbul in the 20th Century (Munich, 2006), pp. 18-38; and Ayfer Bartu, "Who Owns the Old Quarters? Rewriting Histories in a Global Era”, in Çağlar Keyder (ed.), Istanbul: Between the Global and the Local (Lanham, MD, I999), pp. 3 I-47.

17. Suraiya Faroqhi, "Sūk", Encyclopaedia of Islam, I2 vols (Leiden, 1960-2005), X, pp. 796-798. See also Mustafa Cezar, I9. Yüzynl Beyoğlusu (Istanbul, 1991), and Zeynep Çelik, The Remaking of Istanbul: Portrait of an Ottoman City in the Nineteenth Century (Seattle, WA, I986). For department stores located along the Grand Rue de Pera see Köse, "Basare der Moderne", Figure I, p. 348.

I8. Henry Otis Dwight, Constantinople and its Problems: Its Peoples, Customs, Religions and Progress (London [etc.], I90I), p. I7I. That bazaars were anything but "cramped quarters", rather highly complex business districts is revealed in an excellent analysis by Eugen Wirth, Die Orientalische Stadt im islamischen Vorderasien und Nordafrika. Städtische Bausubstanz und räumlichen Ordnung, Wirtschaftsleben und soziale Organisation, 2 vols (Mainz, 2000), I, pp. 102-I5I. 


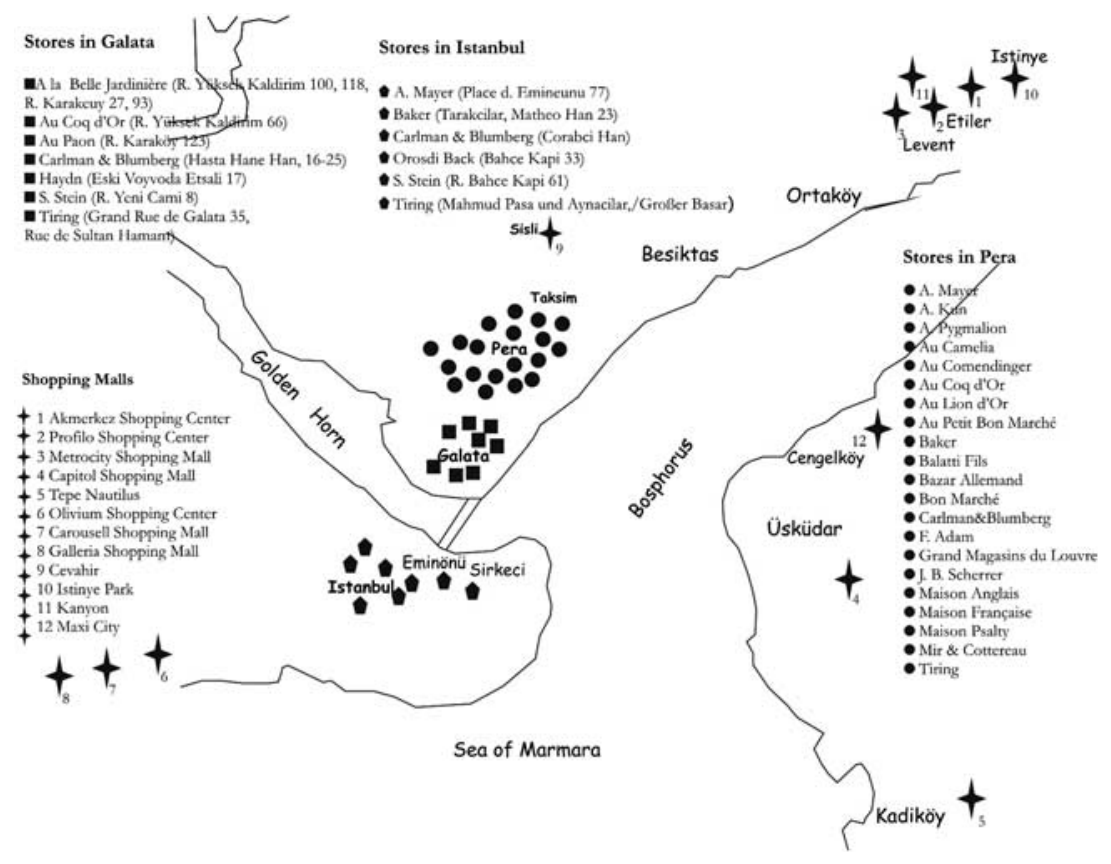

Figure I. Department stores and shopping malls according to location.

a range of goods similar to that offered by their Western rivals. The world of business was much more fluid and hybrid than some observers of the Ottoman capital have suggested (see Figure I).

Before returning to the question of location in the last part of this study, I want to present data on the employees of Western department stores. First, I will discuss their number, ethnic composition, and sex ratio. I will then try to trace the different job types, the duration of employment, as well the earning capacities and career paths that were possible in department stores. The final section discusses the spatial distribution of employees' homes.

For the purpose of the present study, I checked the index of names and addresses given in the $A O$ for the years I $889 /$ I 890 , I909, I9I4, I9I 5 , and I $92 \mathrm{I}$; this yielded more than $\mathrm{I} 20,000$ names in total. ${ }^{19}$ I considered only those department stores employing a large number of the names listed in the index; those were A. Mayer, Baker, Bazar Allemand, Bon Marché, Orosdi Back [hereafter EOB], S. Stein, and Tiring. A. Mayer, S. Stein,

19. The decision to analyse only those volumes relates to the difficulty in accessing other $A O$ volumes. The $A O$ are scattered not only throughout many libraries and archives, but also across a number of countries. A cross-check of earlier issues showed that before the I 890 os only a small number of employees were registered. The volumes after I92 I cease to mention the occupation of those registered. 
Table i. EOB employees

\begin{tabular}{llll}
\hline \multicolumn{1}{c}{$1908 / 1909$} & \multicolumn{2}{c}{$1920 / 1921$} \\
\hline No. of employees & Per cent & No. of employees & Per cent \\
\hline LS: 200 & 100 & LM: $250^{23}$ & 100 \\
AO: 129 & 64.5 & AO: 177 & 70.8 \\
\hline
\end{tabular}

Sources: AO; Louis Salmon, Letters (LS); Moore, "Some Phases of Industrial Life" (LM).

Orosdi Back, and Tiring were of Austrian-Jewish origin; Bazar Allemand of German origin; Bon Marché of Italian, and Baker of British origin. ${ }^{20}$ The data in the $A O$ do not allow one to calculate the total number of employees; also, the stores analysed do not cover all those active in Istanbul. ${ }^{21}$ Still, the data do provide us with invaluable information on employees at Western department stores. The total number of people working in the businesses listed above amounts to approximately I,400 for the years I889 to I92I. Counting every person only once, regardless of whether they appear in more than a single $A O$ volume, we arrive at 56I employees. These data reflect only tentatively all the employees of the stores chosen. Using the EOB department store as an example, we can clarify this assumption, for we do have reliable data for EOB for the years I908/1909 and I920/1921. ${ }^{22}$ Comparing those data with the figures given in the $A O$ for these years, we get the figures which appear in Table I.

Around $1907, \mathrm{EOB}$ was regarded as "certainement les établissements le plus important de notre ville", as Ernest Griaud, secretary-general of the French chamber of commerce in Istanbul, put it. ${ }^{24}$ This five-storey

20. For more details see Köse, Konsumgüterunternebmen.

21. In a survey from 1920, I9 large department stores (no names were given) were surveyed in Galata/Pera ( $\mathrm{I}_{3}$ ) and Istanbul (6). Their employees were classified by sex but not by ethnic background, and their incomes were analysed. The number of employees ranged between 250 (m. 225/w. 25 ) and 8 (m. 7/w. I). If we arrange those stores according to size, the following picture emerges: number with more than 200 employees: I; between I 40 and I00: 3 ; between 95 and 80: 3; between 50 and 30: 4; between 26 and I4: 5; and 9 or 8: 3 . See Laurence S. Moore, "Some Phases of Industrial Life", in Clarence Richard Johnson (ed.), Constantinople Today; or, the Pathfinder Survey of Constantinople - A Study in Oriental Social Life (New York, 1922), pp. 65-201, I73-174.

22. Louis Salmon was an employee of the EOB's Istanbul branch, where he worked between I 908 and I9I4. In letters to his parents he provides us with valuable information about EOB. Copies of these letters were kindly presented to the author by Louis Salmon's son, Yves Salmon. See Köse, “'Maintenant”, and Moore, "Some Phases of Industrial Life”.

23. Since there was no other comparable large department store in Istanbul, the store with 250 employees must be EOB; Moore, "Some Phases of Industrial Life".

24. Ernest Giraud, La France a Constantinople ou Présence française dans la capitale ottomane au début du 20 siècle (Istanbul, 2002) (first publ. 1907), p. го. 
Table 2. Employees according to the AO (I889-I92I)

\begin{tabular}{lrrrrrl}
\hline & 1889 & 1909 & 1914 & 1915 & 1921 & Total/Adjusted \\
\hline A. Mayer & 3 & 28 & 31 & 30 & 25 & $117 / 44$ \\
Baker & - & 33 & 32 & 35 & 19 & $119 / 50$ \\
Bazar Allemand & - & 20 & 26 & 17 & - & $63 / 34$ \\
Bon Marché & 28 & 36 & 29 & 26 & 16 & $135 / 66$ \\
Orosdi Back & 4 & 128 & 226 & 215 & 177 & $750 / 273$ \\
S. Stein & 3 & 41 & 49 & 45 & 20 & $158 / 69$ \\
Tiring & - & 9 & 18 & 16 & 9 & $52 / 25$ \\
Total & $\mathbf{3 8}$ & $\mathbf{2 9 5}$ & $\mathbf{4 1 1}$ & $\mathbf{3 8 4}$ & $\mathbf{2 6 6}$ & $\mathbf{1 , 3 9 4 / 5 6 1}$ \\
\hline
\end{tabular}

Sources: $A O$ I 889 , I909, I9I4, I9I5, and I92I.

building was without doubt the greatest department store in the city, situated not in the Western-style districts of Galata or Pera but in Stamboul (Bahçekap1), and it had more staff than other comparable businesses. With their two- or three-storey premises, S. Stein, Tiring, Baker, and Bon Marché came next. Presumably, the total number of employees must have been perhaps 30 per cent higher than that indicated in the $A O$, although we do not possess any reliable data to confirm that for certain; ${ }^{25}$ a survey of working conditions among employees in Istanbul around 1920 corroborates this assumption though. ${ }^{26}$ Accordingly, the $A O$ provides the data on the number of department store employees as shown in Table 2.

Compared with the number of employees working in urban French or American department stores, the Ottoman data seem very low. The Parisian department stores Bon Marché, Louvre, and Printemps each had between 1,000 and 3,000 employees by the end of the nineteenth century. In I9 1 2, Bon Marché had a staff of $4,500 .{ }^{27}$ Clearly, some of them were as large as industrial firms. ${ }^{28}$ Even department store branches in provincial

25. Since registration in the address index of the $A O$ was voluntary, some employees might have rejected that option. There is no clear indication that the registration of addresses was subject to a fee, as was the case for insertions; $A O$ i 89 I, p. 2.

26. For S. Stein, we know that around 1909 the branch in Cairo had I 80 salesmen; around I9I4 Orosdi Back had 239 employees and the Palacci department some 145 employees; Reynolds, "Commodity Communities", pp. I23-I24, 206. According to Agstner, in I9I6 484 people worked for S. Stein in Cairo; Agstner, "Das Wiener Kaufhausimperium”, p. I39.

27. Homburg, "Warenhausunternehmen und ihre Gründer", pp. 207, 2 I I-2 I 4. For comparable data for the USA see Susan Porter Benson, Counter Cultures: Saleswomen, Managers, and Customers in American Department Stores, I890-1940 (Urbana, IL, I986), p. 34. Around I880, US department stores tended to employ between 400 and 700 "assistants". See Lancaster, The Department Store, p. I33.

28. Benson, Counter Cultures, p. 34 . 
towns, such as Bordeaux, might have had several hundred employees. ${ }^{29}$ Yet, we have to set these businesses in the context of local Ottoman conditions. Firstly, department stores such as EOB, Tiring, and S. Stein had several other branches within the Ottoman Empire besides those in Istanbul, as well as a considerable number of branches and production facilities in Europe. ${ }^{30}$ Moreover, as in Europe, Ottoman retail trade generally consisted of small businesses (petty traders) with few employees. $^{3 \text { I }}$ In terms of numbers of employees, the department stores in Istanbul probably compared favourably even with most urban factories. For instance, around 1920 only a few factories had several hundred workers employed permanently in the capital. ${ }^{32}$

We are able to personalize most of those employees on the basis of the information given in the $A O$. That source allows us to indentify the names, gender, domiciles, and job types of those registered. In a few cases, we are even able to follow their moves and career paths. Information on salaries is not given, of course, but for EOB we can draw on the data given in the letters written by one of its employees, Louis Salmon. ${ }^{33}$ Though it gives names, the $A O$ does not give any indication of nationality or ethnicity. Attempts to determine the ethnicity of employees on the basis of their names is problematic, as Peter Mentzel has argued in his article on the ethnic division of labour on the Ottoman railroad, ${ }^{34}$ but it is not impossible, and several studies have used the technique. Scholars including Edhem Eldem, Ayhan Aktar, Lorans Tanatar Baruh, and Oliver Jens Schmitt have used the method to assign ethnicity to individuals. ${ }^{35}$ Accordingly, I have followed the same methodology and tried to assign the 56I names in my sample to the following ethnic or national categories: Armenian, Greek, Jewish, Levantine/European, and Muslim. Though it would be more correct

29. Theresa M. McBride, “A Woman's World: Department Stores and the Evolution of Women's Employment, I 870-1 920”, French Historical Studies, I० (1978), pp. 664-683, 665 -666. 30. Kupferschmidt, The Orosdi-Back Saga, and Köse, Konsumgüterunternehmen.

3I. Lorans Tanatar Baruh, “2I. yüzyıla girerken. İstanbul tekstil tüccarının profile”, Görüş (Özel sayı: Türkiye Yahudileri) (2003), pp. 64-72, 7I-72. For France, see McBride, “A Woman’s World", p. 666.

32. Moore counted a total of 2,850 workers in factories - including tanneries; Moore, "Some Phases of Industrial Life", p. I74.

33. See Köse, "Maintenant",

34. Peter Mentzel, “The 'Ethnic Division of Labour' on Ottoman Railroads: A Reevaluation”, Turcica, 37 (2005), pp. $22 \mathrm{I}-24 \mathrm{I}$.

35. Edhem Eldem, "Galata'nın Etnik Yapıs1", İstanbul, I (1992), pp. 58-63, idem, "Istanbul 1903-1918: A Quantitative Analysis of a Bourgeoisie", Boğaziçi Journal: Review of Social, Economic and Administrative Studies, I I:I-2 (1997), pp. 53-98; Ayhan Aktar, "Şark Ticaret Yıllıkları'nda 'sarı sayfalar': İstanbul'da meslekler ve iktisadi faaliyetler hakkında bazı gözlemler, I868-I938”, Toplum ve Bilim, 76 (1998), pp. І05-I43; Baruh, “2 I. yüzyıla girerken”; and Oliver Jens Schmitt, Levantiner. Lebenswelten und Identitäten einer ethnokonfessionellen Gruppe im osmanischen Reich im "langen I9. Jahrbundert" (Munich, 2005). 
Table 3. Employees according to ethnicity (I889-I92 I)

\begin{tabular}{|c|c|c|c|c|c|c|c|c|}
\hline & $\mathrm{AM}^{*}$ & GB & BA & $\mathrm{BM}$ & $\mathrm{EOB}$ & SS & TI & Total (\%) \\
\hline \multicolumn{9}{|l|}{ Ottoman } \\
\hline Armenian & $3(6.8 \%)$ & $1(2 \%)$ & $1(2.9 \%)$ & $4(6.1 \%)$ & $59(21.6 \%)$ & $2(2.9 \%)$ & - & $70(12.5 \%)$ \\
\hline Greek & $11(25 \%)$ & $26(52 \%)$ & $23(67.6 \%)$ & $11(16.7)$ & $94(34.4 \%)$ & $37(53.6 \%)$ & $9(36 \%)$ & $211(37.6 \%)$ \\
\hline Jewish & $25(56.8 \%)$ & - & - & - & $73(26.7 \%)$ & $21(30.4 \%)$ & $11(44 \%)$ & $130(23.2 \%)$ \\
\hline Muslim & - & - & - & - & 3 & - & - & $3(0.5 \%)$ \\
\hline \multicolumn{9}{|l|}{ Non-Ottoman } \\
\hline Levantine/ European & $5(11.4 \%)$ & $23(46 \%)$ & $10(29.4 \%)$ & $51(77.3 \%)$ & $44(16.1 \%)$ & $9(13 \%)$ & $5(20 \%)$ & $147(26.2 \%)$ \\
\hline Total & 44 & 50 & 34 & 66 & 273 & 69 & 25 & 561 \\
\hline
\end{tabular}

*AM: A. Mayer; GB: Baker; BA: Bazar Allemand; BM: Bon Marché; EOB: Orosdi Back; SS: S. Stein; TI: Tiring. Sources: $A O$ I889, I909, I9I4, I9I5, and I92I. 
to group Armenians, Greeks, and Jews, as well as Muslims, into a single category, "Ottoman", for my purpose I will present each of them separately. Table 3 shows the number of employees according to their ethnicity.

The cumulative data indicate that a majority of employees were Greek, followed by Levantines/Europeans and Jews. As was the case in many other foreign companies, department stores employed a considerable number of Ottoman citizens, who might sometimes exceed 50 per cent of the total workforce. Surprisingly, except at EOB, Armenians seem to have been employed less frequently in department stores. ${ }^{36}$ Even more striking is the fact that among the $56 \mathrm{I}$ employees, only 3 could be identified as Muslims from their names, all of them working for EOB. ${ }^{37}$ However, one photograph taken of EOB staff in around 1900-1910 depicts around 30 workers/servants, and most probably of Muslim origin. The photograph has on the back the inscription Bekçi - Hamallar. Those workers are not mentioned in the $A O$, nor are the approximately 40 children who, according to another photograph, were assembling umbrellas in 2 ateliers (semsiye fabrika) on the top floor of the EOB building. ${ }^{38}$

\section{THE LADIES’ PARADISE: MALE-DOMINATED WORLD}

Beginning in $1889 / 1890$ the $A O$ lists the names of a few female employees; altogether, before 1920 we have the names of six women, who could be assigned Levantine or Jewish ethnicity. It might be surprising that department stores, which are generally thought of first and foremost as tending to the needs of women and considered a "world of women", ${ }^{39}$ should employ mainly male workers; (Au Bonbeur des Dames was the title Zola gave to his novel about Bon Marché). Yet, even in the shops in France, male employees dominated the scene; it was not until around I9I4 that the gender imbalance changed in favour of women..$^{40}$ Apparently, the situation in Istanbul was the same, for four of the six women are listed for the first time in the $A O$ for igr4. As mentioned above, we have to assume the proportion of female employees was higher. The survey of Istanbul department stores carried out by Laurence Moore in 1920 clearly indicates that, starting from I9I4, more and more women were hired, first

36. They accounted for only a small proportion of staff at branches of the Singer Sewing Machine Company - at least as far as we know for Istanbul. See $A O$ i909, I9I4, and I9I 5.

37. Osman Refik (R. Fazli Pacha, Stamboul), Refik Mehmed (Tchemberli Tach), and Refik Osman (Tchemberli Tach). See $A O$ I 909 and I9I4. According to Reynolds, a document from I9I4 lists 237 EOB employees in Cairo, most of them "appeared to be Jews or Christians", yet "more than half of those included (I 29 people) were listed by the firm as 'local citizens' or had Muslim names"; Reynolds, "Commodity Communities", pp. I23-I 24.

38. Ircica Photo Archive, 91539-25 and 91539-26 (Istanbul).

39. McBride, “A Woman's World", p. 666.

40. Ibid. 
Jews, then Greeks. Only after World War I did Muslim women begin to occupy positions formerly occupied by men.

According to Moore, the gender ratio in the thirteen stores situated in Galata and Pera was 427 men to 270 women ( 38.7 per cent female), whereas in the 6 stores situated in traditional Istanbul it was 358 men to 80 women (I 8.3 per cent female). ${ }^{4 \mathrm{I}}$ With just 25 women out of a total of 250 employees, EOB, which is included among the latter 6 stores, was well below the average. ${ }^{42}$ Moore informs the reader that Greek women were initially resistant to working in department stores and that only the war provoked a change in their attitude. ${ }^{43}$ Women were generally engaged as cashiers and accountants, a practice that seems to have become common by 1920 , not least because women worked for lower wages. As for Muslim women, Moore quotes the opinion of Muslim proprietors: "In the Turkish stores, the proprietors spoke more highly of the service of the women; women were said to be more conscientious and honest than men, and almost their equal in ability, although their experience in the business world had been so short." ${ }^{\prime 4}$

\section{"WORKERS EMPLOYED ON THE FRONTLINE OF CONSUMPTION": ${ }^{45}$ JOB TYPES IN WESTERN DEPARTMENT STORES}

In department stores, customer service was at their core; therefore, salesmen and saleswomen, as well as sales assistants, were crucial in the various departments of the stores. The majority of the individuals listed (450), designated as "employee", probably worked in customer service. The remaining 108 could be assigned to four categories of job types, as Table 4 illustrates. ${ }^{46}$

4I. Moore, "Some Phases of Industrial Life", p. I8 3 . Fourteen children under fifteen years worked in the shops in Galata and Pera, while only three were listed for the six enterprises in Istanbul. 42. Without giving a year, Reynolds asserts that "salesclerks included nearly equal numbers of men and women". Assuming the data relate to the period before I9I4, the situation in Cairo must have been considerably different from that in Istanbul or major European cities; Reynolds, "Commodity Communities", pp. I86-188. Yet in the I9I 4 list only I 3 of the 239 (on p. I 23 she gives 237) workers were female (5.4\%); ibid., p. 208.

43. For Greeks and their conservative consumption behaviour, see Haris Exertzoglou, "The Cultural Uses of Consumption: Negotiating Class, Gender, and Nation in the Ottoman Urban Centers During the 19th Century", International Journal of Middle East Studies, 35 (2003), pp. 77-IOI.

44. Moore, "Some Phases of Industrial Life", p. I 88.

45. Lancaster, The Department Store, p. I25.

46. These job types could be found in European stores too. See Lancaster, The Department Store; Christopher P. Hosgood, “Mercantile Monasteries': Shops, Shop Assistants, and Shop Life in Late Victorian and Edwardian Britain", The Journal of British Studies, 38 (1999), pp. 322-352; and M.B. Miller, The Bon Marché: Bourgeois Culture and the Department Store, I 869-I920 (Princeton, NJ, I98I). 
Table 4. Job types in department stores*

\begin{tabular}{|c|c|c|c|}
\hline Customer service & Finance/Office & Imports & Management \\
\hline Cutter & Cashier & Employee (customs) & Correspondence clerk \\
\hline First cutter & Chief cashier & $\begin{array}{l}\text { Employee (goods } \\
\text { clearance) }\end{array}$ & Inspector \\
\hline Second cutter & Accountant & Chief employee (goods & General manager \\
\hline Chemisier & Controller & clearance) [dédowaner] & Director's secretary \\
\hline Worker-tailor & Chief clerk & & Deputy director \\
\hline Tailor & Administrator & & Director \\
\hline Chief tailor & Office worker & & \\
\hline Employee & Secretary & & \\
\hline Saleswoman & & & \\
\hline Shop walker & & & \\
\hline Carrier & & & \\
\hline $\begin{array}{l}\text { Security - Door } \\
\text { keeper }\end{array}$ & & & \\
\hline
\end{tabular}

*Note: Job types given in bold could be found in all department stores (only in the case of Tiring were "cutters" not listed).

Sources: $A O$ I889, I909, I9I4, I9I5, and I92I.

Positions such as those of cashier and accounting clerk were held mainly by Ottoman Greeks and Armenians. Greeks, Jews, and Levantines are listed as tailors and couturiers. Office jobs and higher management positions were held by Europeans and/or European Jews, depending on the department store.

Again, the EOB case may exemplify the occupational distribution according to ethnicity. Table 5 overleaf clearly shows that, according to the relationship between job type and ethnicity, there were variations among department stores. Greeks working for EOB are listed mainly as "employee", whereas more Armenians than in other department stores were deployed in middle-ranking positions. In A. Mayer, S. Stein, and Tiring, high proportions of Jews were employed. The top jobs were also occupied by Jews, who, unlike the majority, came from Austria.

\section{INCOME OF EMPLOYEES: COMPARISON OF SALARIES}

The $A O$ does not provide data on income; we must therefore rely on other sources. Wage ledgers might have existed for department stores, but unfortunately not a single one has been discovered so far. Fortunately, personal letters from Louis Salmon, an employee of the Istanbul branch of EOB, give us interesting hints on the income situation. Since we have no comparable information on other department stores, the data given do not allow any generalizations. Wage data for other sectors and data on department stores and other businesses with clerks in western Europe nevertheless help us to get a clearer picture. 
Table 5. EOB: Job types according to ethnicity/nationality (I908/I909)

\begin{tabular}{lccl}
\hline Ethnicity/Nationality & Total & Employees & Higher positions \\
\hline Austrian Jews & 10 & 5 & 1 Director \\
& & & $\begin{array}{l}\text { 1 Deputy director } \\
\text { 1 Inspector }\end{array}$ \\
& & & 2 Accountants \\
Jews & 38 & 35 & 1 Chef dédouaner (customs) \\
Greeks & 35 & 35 & 2 Accountants \\
Armenians & 27 & 21 & 2 Shop walkers \\
& 19 & 17 & 4 Accountants \\
Levantines & 129 & 113 & 16 Cashier \\
Total & $c .30$ & $c .30$ & Janitor/carriers \\
Muslim Ottomans & 40 & 40 & Umbrella assembly \\
Children & 200 & 200 & \\
Adjusted total & & & \\
\hline
\end{tabular}

*Note: One "Chef du Rayon" not listed in the AOs but mentioned by Louis Salmon is added here.

Sources: Louis Salmon, Letters, AO I909.

On 22 September 1908, I65 EOB employees declared a strike, which lasted about two weeks. ${ }^{47}$ Their main demand was a wage increase $(20,30$, and 40 per cent, depending on income level). In letters to his parents during the strike, Louis Salmon provides us with the income levels presented in Table 6. I have contrasted those data with figures provided by Mentzel, who extracted them from a ledger listing 669 salaried employees at the Ottoman Anatolian Railroad Company (CFOA). The ledger was compiled in August I908 and includes employees with relatively high incomes, who, according to Mentzel, "by the standards of late Ottoman society" had very well-paid jobs. ${ }^{4}$

EOB employees were highly paid compared not only with other Ottoman employees of the period; even in relation to salaries of employees in European department stores (London, Paris, and Hamburg), EOB salaries appear to have been well above average. ${ }^{49}$ Whereas skilled

47. For the strike see Köse, "Maintenant".

48. Mentzel, "The 'Ethnic Division of Labor'”, p. 23 I.

49. Women in comparable positions earned between 25 and 50 per cent less. See Benson, Counter Cultures; Hosgood, "Mercantile Monasteries'”; and Michele L. Peterson, "Commercial Assistants or White-Collar Workers? Male and Female Clerks in Turn-of-the-Century Hamburg" (unpublished Ph.D. dissertation, University of Pittsburgh, 1994). According to Moore's survey, the difference in income level between men and women in department stores varied from 5 to I 5 per cent; it was only at the highest salary rates that the difference was anything up to 20 per cent; Moore, "Some Phases of Industrial Life", p. I 87. 
Table 6. Income level at EOB (1908) and CFOA (1908)

\begin{tabular}{llll}
\hline $\begin{array}{l}\text { Orosdi Back } \\
(\text { EOB })\end{array}$ & $\begin{array}{l}\text { Kuruş per } \\
\text { month }\end{array}$ & $\begin{array}{l}\text { Ottoman Anatolian Railroad } \\
\text { Company (CFOA) }\end{array}$ & $\begin{array}{l}\text { Kuruş per } \\
\text { month }\end{array}$ \\
\hline Low & $250-500$ & Low & $500-1,000$ \\
Middle & $500-1,000$ & Middle & $1,000-2,000$ \\
Upper & $1,000-1,700$ & Upper & 2,000 \\
& $1,700-4,200$ & & 5,000 \\
\hline
\end{tabular}

Sources: Louis Salmon, Letters, Mentzel, “The 'Ethnic Division of Labor'”, p. 224.

workers in Europe could earn much more than clerks, the EOB and CFOA cases indicate that the Ottoman situation could differ in this respect.

According to Donald Quataert, unskilled coalfield workers earned about 6 kuruş a day ${ }^{50}$ (22 lira per annum), and a baker's yearly income in I 908 was about 50 lira ( 14 kuruş a day, assuming he worked every day). Between I900 and I9I3, employees of companies such as Şirket-i Hayriye, Ziraat Bankas1, and the Tobacco Régie received annually between 55 and 72 lira ( I 5-20 kuruş a day). The annual income of lower-level civil servants from I900-1909 varied between 240 and I,000 lira, according to their rank; in the middle and upper echelons of the civil service, incomes could be between 2,400 and 5,160 lira, ${ }^{5 \mathrm{I}}$ which considerably exceeded those of most salaried employees, except the general directors of EOB. ${ }^{52}$

Louis Salmon himself was in management; after joining the Istanbul branch of $\mathrm{EOB}$ in 1908 , he worked his way up to the top, becoming branch director in Thessalonica in I9I4. Through his letters to his parents, we can observe how his wages grew steadily. He received around I4 lira monthly in his first year, I8.4 in I910, 27 lira two years later, and, finally, in I9I 4 , almost 38 lira a month. ${ }^{53}$

50. Donald Quataert, "Unpaid Ottoman Coal Miners during the early 2oth Century", in Vera Costantini and Markus Koller (eds), Living in the Ottoman Ecumenical Community: Essays in Honour of Suraiya Faroqhi (Leiden, 2008), pp. 247-264, 252; Donald Quataert, Miners and the State in the Ottoman Empire: The Zonguldak Coalfield, I822-I920 (New York, 2006).

5I. See also Carter Vaughn Findley, "Economic Bases of Revolution and Repression in the Late Ottoman Empire", Comparative Studies in Society and History, 28 (1986), pp. 81-106, 86-88. 52. General directors received - besides their salary - a share of 6 per cent of all net profit in excess of I.5 million francs per annum. In 1904, that share totalled 75,000 francs (3,000 lira). See Jacques Thobie, "Sur quelques societies oubliées à capitaux francais dans l'Empire ottoman", in Hamit Batu and Jean-Louis Bacqué-Grammont (eds), L'Empire ottoman, la République de Turquie et la France (Istanbul, 1986), pp. 374-390, 393. According to Kupferschmidt, Joseph Back, general director of the Istanbul branch around I9I4, earned 300 lira a month; Kupferschmidt, The Orosdi-Back Saga, p. 44. 53. For London, the salaries given are those of clerks from a range of companies such as banks and insurance companies covering the years 1905-1910. According to Michael Heller, "these 


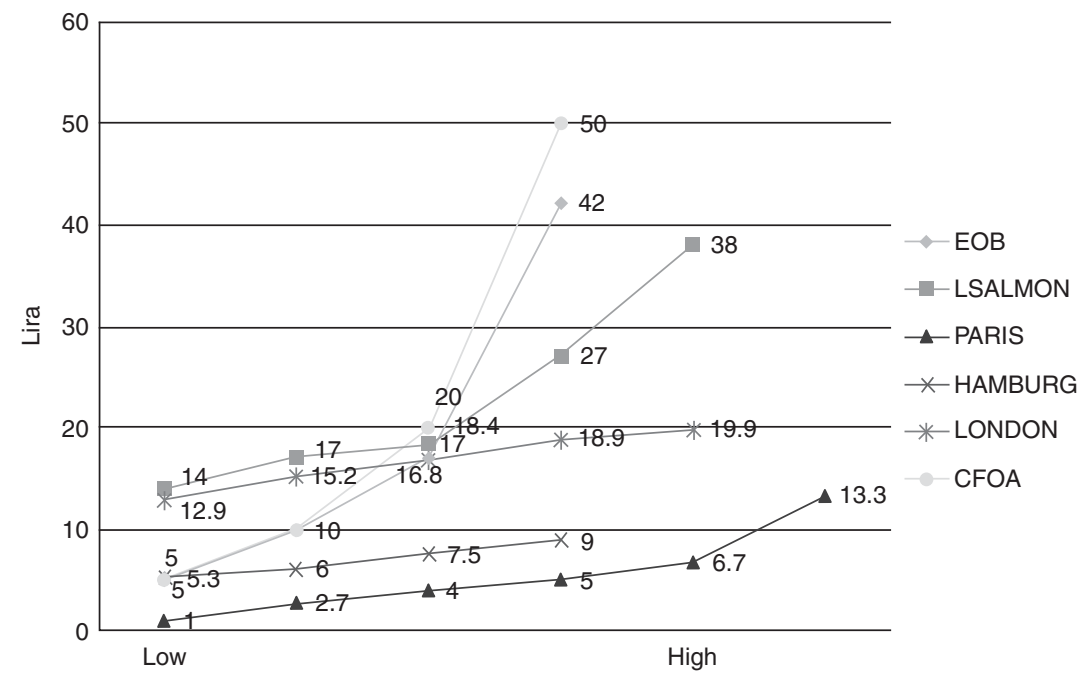

Figure 2. Comparison of monthly income, 1900-1914 (in lira).

Note: All figures have been translated into lira. The following exchange rates - which remained relatively stable for the sample period - were used: $£_{I}=5$ US $\$=20$ Deutschmarks $=25$ French francs $=\mathrm{I}$ lira $=100$ kuruș ( $\mathrm{I}$ kuruș $=40$ para). See Charles Issawi (ed.), The Economic History of Turkey, I800-1914 (Chicago, IL, I980).

Sources: Lancaster, The Department Store; Hosgood, "Mercantile Monasteries", Peterson, Commercial Assistants, Miller, Bon Marché, Vedat Eldem, Osmanl Imparatorluğu'nun iktisadi şartları bakkında bir tetkik (2nd edn, Ankara, 1994), pp. I43, I53, and Louis Salmon, Letters.

\section{CAREER PATHS: FROM EMPLOYEE TO EXECUTIVE}

Unfortunately, we have little information on the hiring procedures of department stores. In response to the two-week strike mentioned earlier, EOB tried to replace some of the strikers. To do so, it used local newspapers to recruit new workers and received i 50 applications. Given the quick response - Io० came for job interviews - it might have been normal practice to hire employees through announcements in the local press. ${ }^{54}$ Moreover, the hiring probably depended also on personal contacts. Louis Salmon was hired through his father, Felix Salmon, who worked for thirteen years as general manager for EOB Paris. Louis received incompany training, starting at the age of eighteen in EOB's branch in Manchester (I90I), followed by training in Hamburg (1904), and finally, from I908, after his military service, he continued his employee training

salaries are taken from the better paid segments of the clerical profession”. See Michael Heller, "Work, Income and Stability: The Late Victorian and Edwardian London Male Clerk Revisited", Business History, 50:3 (2008), pp. 253-271, 256-257, and 260.

54. Köse, "Maintenant", pp. I I6-1 17. 
in the Istanbul branch. There, he worked in all departments, eventually working his way up to management. 55

The $A O$ entries indicate that local employees too could improve their occupational positions. George Meimaridis, for instance, is registered in I9I4 as an employee at Baker; by I92 I his occupational title had changed: he was now responsible for clearing goods for Baker (dédonaner). In I909, Jules Bernard began his career at Bon Marché as an employee; six years later, he became cashier. His colleague, Pierre Louis Bocagnano, who joined in I889, had a more impressive career: in I9I4, he became executive director of the store. Dom Bocagnano, probably a relative, rose within twelve years from being an employee to being cashier. The entries for EOB list four individuals who started out as employees and became accountants or accountants who became chief accountants.

Interestingly, we also find career paths suggesting downward occupational mobility. Pierre Terdjiman seems to have lost his position as accountant between I909 and I9I4 and was demoted to EOB employee. Other entries suggest that relatives worked in different enterprises, and, for some, switching stores was a career option. ${ }^{56}$ For instance, Léon Bornstein worked as chief cashier at S. Stein between I 889 and I9I3. But in the $A O$ for I9I4 and I9I5 he is listed as an executive of the A. Mayer department store. Finally, in I92 I, he again switched employer, moving to Tiring as a cashier.

Although the $A O s$ do not mention the unskilled workers (bizmetçi, kapıcı, bekçi), those workers were part of the department store staff. As already mentioned, EOB employed around thirty carriers and janitors. It is highly probable that for the majority the opportunity for advancement was limited; yet the memoirs of Georg Mayer, director of the A. Mayer department store in the early Republican period, provides an example that is interesting in two ways. Firstly, it seems department stores recruited their unskilled workers among Anatolian families, partly over several generations. Secondly, in the case of the servant (bizmetçi) Has[s]an, we see an unskilled worker who managed to teach himself how to read and write and who gradually rose to positions with more responsibility. $\mathrm{He}$ was, for instance, head of the store's own parcel service and was later responsible for clearing goods at customs. We learn that he finally

\section{Ibid.}

56. All in all, ten identical names appeared in the sample. Though not all were necessarily related, the following individuals might have been relatives: Antoine Barthélemy (caissier); R. Baghtché, 4/R. Baghtché, 56; Ferikeuy and Armand Barthélemy (employé); both worked for EOB between I908 and I92 I. Also Jean Dapei(y) (employé), R. Zeren, 8, from I9I4 in Bazar Allemand, and Jeanne Dapey (vendeuse), R. Ainaly Tcheschmé/R. Zeren, 8, employed by Baker (1914-192I). Israel Misrachi (employé) and Isaac Misrachi (employé), both residents in Sirkedji, worked for EOB (in I909-19I4 and I909-192 I respectively). Finally, Mathieu Persekoff was employed by Baker between I9I4 and I92 I and Francois Persekoff by Bon Marché; they both had the same address (R. Fakir, 24, Pera). 
managed to bring his family to Istanbul, where his children could attend school and, later, even university. ${ }^{57}$

\section{WORKING CONDITIONS: CUSTOMER-FRIENDLY AND DISCIPLINED}

Regardless of career paths, some department stores apparently provided their employees with different models of earnings and social security, including performance-related profit sharing, annual sales commission, temporary continuation of salary, and pensions. ${ }^{58}$ Yet this form of employee social security should not hide the fact that the organization of department stores was highly hierarchical and similar to the patriarchal organizations of their European counterparts. Again, the letters of Louis Salmon give us some clues as to working conditions. According to the written demands of the striker that Salmon refers to in one of his letters, the ethnically mixed staff (and most probably unskilled workers) claimed religious holidays according to their own rites (Armenian, Greek Orthodox, Jewish, and Muslim). Further, employees worked between ten and twelve hours a day. As in Europe and America, a reduction in working hours was one of their demands during the wave of strikes in $1908 . .^{59}$

Another interesting request relates to dismissals, which often seem to have been immediate and unfair. The strikers accepted dismissals on grounds only of theft or lack of discipline. Salmon's description of his daily work reveals that he too was subjected to rigid discipline. We may assume that, as at the Ottoman branches of European stores, "written and unwritten" laws existed, non-compliance with which would be punished by fines or even dismissal. ${ }^{60}$ A well-groomed appearance and, above all, accuracy were essential. Further, employees were expected to be customerfriendly and confidently multilingual. ${ }^{6}$ Immediately after his arrival, Louis Salmon, who had already mastered English and German by the time he joined the Istanbul branch, was asked by the director Leopold Back to begin Turkish courses, which he did. ${ }^{62}$ Even if working conditions in Istanbul seem to have been very similar to those experienced by American and European employees, the willingness of Ottoman department workers to

57. Georg Mayer, Türkischer Basar. Geheimnisse orientalischer Geschäftstüchtigkeit (Heilbronn, 1978), pp. 64-70.

58. Moore, "Some Phases of Industrial Life", pp. I88-189; Lancaster, The Department Store, pp. I4I-I 45 .

59. Köse, "Basare der Moderne". In 1920 the length of the working day in department stores varied from seven and a half to ten hours; Moore, "Some Phases of Industrial Life", p. I84.

60. For punishments in department stores see Lancaster, The Department Store.

6r. Agstner, "Wiener Kaufhausimperium”, p. I30.

62. Letter to his father (I I February 1908). 
Table 7. Duration of employment in years (I889-192I)

\begin{tabular}{lcrcccc}
\hline & 1 & 2 & $5-7$ & 12 & $20-26$ & $>30$ \\
\hline A. Mayer & 11 & 2 & 19 & 12 & 1 & - \\
Baker & 10 & 4 & 27 & 9 & - & - \\
B. Allemand & 13 & 9 & 12 & - & - & - \\
Bon Marché & 35 & 7 & 7 & 6 & 5 & 6 \\
Orosdi Back & 53 & 24 & 120 & 73 & 3 & - \\
S. Stein & 20 & 10 & 28 & 8 & 3 & - \\
Tiring & 8 & 5 & 11 & 1 & - & - \\
Total & 150 & $\mathbf{6 1}$ & $\mathbf{2 2 4}$ & 109 & 12 & $\mathbf{6}$ \\
\hline
\end{tabular}

Sources: $A O$ I889, I909, I9I4, I9I5, and I92I.

show solidarity with the working class and call for a strike is something that distinguishes them clearly from their counterparts elsewhere. ${ }^{63}$

\section{DURATION OF EMPLOYMENT}

Nevertheless, most male employees seem to have held secure positions, for more than 40 per cent of the persons listed worked at the same department store for between 5 and 7 years, and around 20 per cent for I 2 years. Although I 50 individuals appear in just one issue of $A O$, we also find I 8 who must have worked for 20 or even more than 30 years. We even have a few rare cases which suggest that it was not impossible to work more than 50 years at the same establishment. ${ }^{64}$ Working for department stores usually meant a secure position.

\section{EMPLOYEE'S DOMICILE: FROM ETHNIC DISTRICT TO THE FASHIONABLE PERA QUARTER}

It is striking that a majority of the I08 qualified staff (i.e. non-sales) lived in Pera. By the end of the nineteenth century, living in Pera was considered highly expensive, and for many it was a prestigious place to stay. ${ }^{65}$ Those who could climb the occupational ladder would often change their domicile (for instance from Galata to Pera or from Haskeuy to Pera).

63. During the strike wave of 1908 four other strikes at department stores are mentioned; Köse, "Maintenant". For Europe, see Siegfried Kracauer, Die Angestellten. Aus dem neuesten Deutschland (Frankfurt am Main, 197I) (first publ. 1929). The absence of protest among European employees is explained by Hosgood in terms of "lower-middle-class docility"; Hosgood, “'Mercantile Monasteries'”, p. 352.

64. Fritz Rosenthal, who is not among the employees listed at A. Mayer, is known to have worked there for sixty years. See Bali, "Mayer Mağazası ve Georg Mayer", p. xx.

65. "Constantinople", Chambre de Commerce Francaise de Constantinople Bulletin Mensuel, 64 (3 I July i 892), pp. 8-9. 


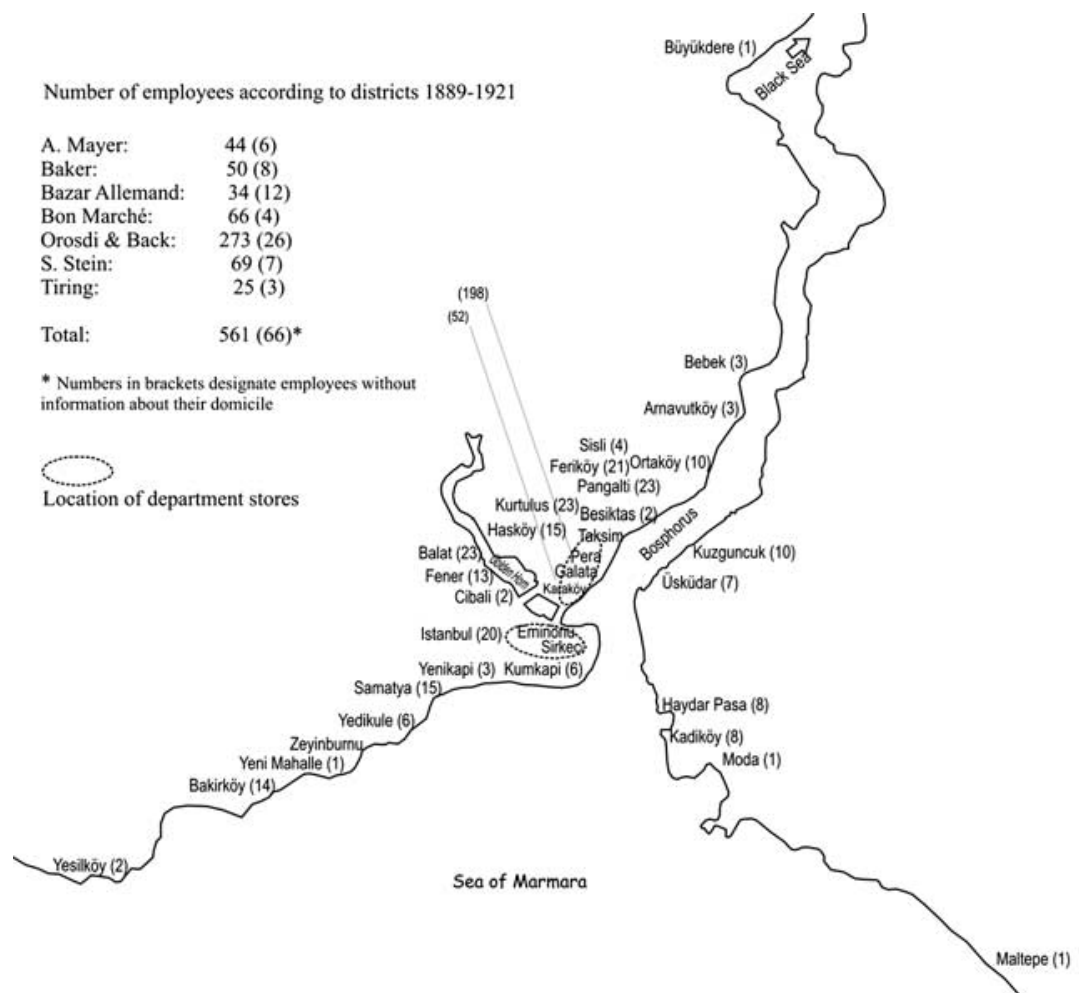

Figure 3. Number of employees according to domicile.

However, several individuals in senior positions moved from Pera to other districts, such as Ferikeuy, or just a few blocks within their former districts (R. Baghtché 28, Ferikeuy to R. Baghtché 56 , Ferikeuy or from R. Hamam 68, Pancaldi to R. Hamam 44, Pancaldi). All but one executive had a domicile either in Pera or in Galata.

Generally, the $A O$ entries reveal a connection between the domicile and ethnic background of employees. Many employees lived in the same districts in which their ethnic group had lived for generations. Pera was the quarter most favoured by Greeks, Levantines, and Europeans. Table 8 lists all employees according to their domicile.

Edhem Eldem's study of Ottoman banks' customer registers provides a similar ethnic-based domicile pattern. ${ }^{66}$ According to the $A O$, during the late nineteenth century, Galata, a traditional business district, was inhabited predominantly by Jews. Riva Kastoryano has shown that by then

66. Eldem, "Istanbul 1903-1918”, pp. 76-79. 
Table 8. Employees according to domicile and ethnicity (I889-I92I)

\begin{tabular}{|c|c|c|c|c|c|c|}
\hline Districts* & A & G & $\mathrm{J}$ & $\mathrm{L} / \mathrm{E}$ & TM & Total \\
\hline Pera & 17 & 80 & 36 & 65 & - & 198 \\
\hline Galata & 3 & 5 & 34 & 10 & - & 52 \\
\hline Pancaldi & 5 & 2 & - & 16 & - & 23 \\
\hline Balat & 1 & 12 & 10 & - & - & 23 \\
\hline Tatavla & 1 & 22 & - & - & - & 23 \\
\hline Ferikeuy & 2 & 5 & - & 14 & - & 21 \\
\hline Stamboul & 3 & 7 & 4 & 3 & 3 & 20 \\
\hline Haskeuy & 1 & 2 & 11 & 1 & - & 15 \\
\hline Makrikeuy & 4 & 9 & 1 & - & - & 14 \\
\hline Psamatia & 5 & 10 & - & - & - & 15 \\
\hline Phanar & 1 & 12 & - & - & - & 13 \\
\hline Couscoundjuk & 1 & 2 & 6 & 1 & - & 10 \\
\hline Ortakeuy & 3 & 2 & 4 & 1 & - & 10 \\
\hline Haydar Pacha & - & - & 8 & - & - & 8 \\
\hline Kadikeuy & 1 & 4 & - & 3 & - & 8 \\
\hline Scutari & 4 & - & 3 & - & - & 7 \\
\hline Yedi Koule & - & 5 & - & 1 & - & 6 \\
\hline Coum Capi & 6 & - & - & - & - & 6 \\
\hline Chichli & - & - & - & 4 & - & 4 \\
\hline Yeni Kapi & - & 3 & - & - & - & 3 \\
\hline ArnAOutkeuy & - & 3 & - & - & - & 3 \\
\hline Bebek & 1 & - & - & 2 & - & 3 \\
\hline Béchiktache & 1 & 1 & - & - & - & 2 \\
\hline S. Stefano & - & 2 & - & - & - & 2 \\
\hline Djoubali & - & 2 & - & - & - & 2 \\
\hline Bouyoukdere & 1 & - & - & - & - & 1 \\
\hline Yeni Mahalle & - & 1 & - & - & - & 1 \\
\hline Maltepe & - & 1 & - & - & - & 1 \\
\hline Moda & 1 & - & - & - & - & 1 \\
\hline
\end{tabular}

*Notes: The district names are given as in the AO. Today, some of those places have different names: Chichli $=$ Şişli; Djoubali $=$ Cibali, Tatavla $=$ Kurtuluş, Makrikeuy $=$ Bakırköy, Psamatia $=$ Samatya, Phanar $=$ Fener, San Stefano $=$ Yeșilköy, and Scutari = Üsküdar.

A: Armenian; G: Greek; J: Jewish; L/E: Levantine/European; TM: Turkish Muslim. Sources: $A O$ I889, I909, I9I4, I9I4, and I92I.

Galata was regarded as a transit quarter to the more prestigious Pera, where at least 36 Jews lived. ${ }^{67}$ Abraham Galanté's assumption that at the end of the nineteenth century traditional Jewish districts such as Balat, Hasköy,

67. Riva Kastoryano, "Passage par Galata: Mobilité Sociale des Juifs d'Istanbul”, in Edhem Eldem (ed.), Première Rencontre Internationale sur l'Empire Ottoman et la Turquie Moderne, Institut National des Langues et Civilisations Orientales, Maison des Sciences de l'Homme, I8-22 janvier 1985. I. Recherches sur la ville ottomane: La cas du quartier de Galata (Istanbul, 1992), pp. I7I-18I. See also Schmitt, Levantiner, pp. 444-446, 474-478, and Eldem, "Galata'nın etnik yapısı". 
and Haydarpaşa had already been vacated in favour of Galata and Pera seems to be confirmed by the data. ${ }^{6}$ Only 2.6 per cent of the 190 Greeks had their domicile in Galata; besides Pera, they lived mostly in Tatavla (2 I), Balat (I2), and Phanar (I2), followed by Psamatia and Makrikeuy. More than half of Europeans/Levantines resided in Pera, followed by Galata (IO), Feriköy, and Pancaldi. Only 27 per cent of Armenian employees lived in Pera; the rest were distributed equally across Coum Capi, Pancaldi, Makrikeuy, Scutari, Psamatia, Galata, and Ortakeuy.

Although the almost 500 employees lived in a total of over 28 districts, the great majority - between 60 and 80 per cent - were concentrated in just 4 districts, according to their ethnic group. Finally, the data clearly show that the majority of employees had their own homes (see Figure 3). This contrasts with department stores in Europe, where many employees had accommodation in the store itself. The living-in system for employees, which was common in England, seems not to have been in use in Istanbul. ${ }^{69}$ Yet again, Georg Mayer's memoirs are revealing in this respect, for he mentions Turkish servants who were accommodated in the store. ${ }^{70}$

\section{CONCLUSION: FROM DEPARTMENT STORES}

TO MEGA MALLS

Western department stores played an important role in Istanbul's retail trade in the late nineteenth and early twentieth centuries. They were important economic actors and employed hundreds of local citizens. Socially and culturally, as well as architecturally, they left deep traces in the urban web of the Middle East. For the history of consumption and the modernization of shopping, they form a sort of link between the "traditional bazaar" and the postmodern mega mall. Department stores were inspired by the bazaar concept and, as the examples presented here show, they were not restricted only to the Western-style districts of Istanbul but were also active in districts traditionally associated with the bazaar. Therefore, spatially, there was probably no such clear-cut separation of modern and traditional business. Population, easy accessibility, easy transportation, and distribution played decisive roles in the choice of location within the capital.

The workforce was equally highly mixed, dominated by Ottoman citizens, even though Muslims were, apparently, hardly ever employed as

68. Abraham Galanté, Histoire des Juifs d'Istanbul depuis la prise de cette ville en 1453, par Fatih Mebmed II. jusqu'à nos jours (Istanbul, I94I), pp. 49-69.

69. Lancaster, The Department Store; Hosgood, “Mercantile Monasteries"; and McBride, "A Woman's World". According to Faroqhi "[S]ome craftsmen practised their craft at home, and had living-in apprentices"; Faroqhi, "Sūk", p. 796. The bazaars, on the other hand, had no such mixed functions; Wirth, Die Orientalische Stadt.

70. Mayer, Türkischer Basar, pp. 69-70. 
sales personnel before I9I4. In most stores, the majority of workers were Greek, Armenian, or Jewish. The question of why Muslims apparently worked mostly in minor positions (bizmetçi, bekçi, hamal) is not easy to answer. We observe a similar situation in comparable enterprises active in Istanbul selling consumer goods. ${ }^{7 \mathrm{I}}$ This might be interpreted as some sort of ethnic-based hiring policy; but, as yet, that remains just a hypothesis.

In the case of women, Ottoman department stores did not differ much from Western ones. It was only from I 914 onwards that female employees equalled male employees in number. Nevertheless, women were important to Muslim customers, as were special rooms, for they allowed the stores to offer culturally and religiously sensitive services.

The personnel management of Istanbul's department stores shows great similarities to that of European and American ones. Patriarchal structures based on the family business origins of the enterprises - and severe discipline were important features on both sides.

The incomes of employees seem to have been well above the average for unskilled workers and favourable even when compared with the salaries offered by European department stores. Most executives of European or American department stores were probably not afraid of strike calls; in I 908 at least, the situation in Istanbul (and Thessalonica) was slightly different. One possible reason might be the relative distance between workplace and domicile. Whereas employees in Europe often lived within the department store, where they were subject to a "welfare system" and social control, most Ottoman employees had their own homes. According to the data, most employees lived in more or less ethnically homogenous districts within a radius of $5-15$ kilometres of their workplace. The social impact of each ethnic community might have been of more relevance than the impact of the department stores, which implies that the staff did not form a conscious body of employees detached from workers, as was the case in Europe. ${ }^{72}$ This may explain the willingness of the Ottoman employees to strike with the workers.

Western department stores seemingly bridged the spatial gap between traditional and modern districts by operating branches on both sides and working with local traders and manufacturers alike. The choice of location was as much a part of their marketing as the intensive advertising and promotional activities designed to appeal to all potential customers. Today, Western department stores, both on the Istiklal Caddesi (the former Grand Rue de Pera) and in the old town (Stamboul), have been replaced by other foreign and/or local enterprises. In addition to the Istiklal Caddesi, which today offers consumer goods in the lower- and 
middle-price segment, many more shopping districts have developed which appeal to well-off consumers (Bağdat Caddesi, Osmanbey, and Nişantaşı). The famous Grand Rue de Pera lost its appeal to the bourgeois flâneur a long time ago. Furthermore, since the I990s, mega malls have been erected first in suburban areas, which could be reached by car, and then, with the developing transport network, in districts easily accessible by metro (see Figure I). Their location seems also to depend on the income level of the neighbourhood rather than factors such as population density. The Grand Bazaar outlived the department store and coexists with these new vertical bazaars of postmodernity, the mega malls. The latter now attract not just millions of consumers, but, increasingly, researchers as well. ${ }^{73}$

73. Ayşe Durakbaşı and Dilek Cindoğlu, "Encounters at the Counter: Gender and the Shopping Experience", in Deniz Kandiyoti and Ayșe Saktanber (eds), Fragments of Culture: The Everyday of Modern Turkey (New Brunswick, NJ, 2002), pp. 73-90. For an early article on malls in Istanbul, see Ayşe Hür, "Alışveriș Merkezleri”, Dünden bugüne İstanbul Ansiklopedisi, I (I993), pp. I87-I 88; Mustafa Sönmez, “İstanbul'un Hipermarketleri”, İstanbul (July 1997), pp. IOI-IO4; and Susan Thorne, "Turkey Greets World's Retail Execs With Vibrant Industry, Economy", Shopping Centers Today (April 2005), available online at http://www.icsc.org/srch/ sct/scto405/cover_3.php [last accessed 20 June 2009]. For Egypt, see Mona Abaza, "Shopping Malls, Consumer Culture and the Reshaping of Public Space in Egypt", Theory, Culture E Society, I 8 (200I), pp. 97-I 22. 